\title{
Induction of Rhizopus oryzae Germination Under Starvation Using Host Metabolites Increases Spore Susceptibility to Heat Stress
}

\author{
Tidhar Turgeman, Nathan Kakongi, Avishai Schneider, Yakov Vinokur, Paula Teper-Bamnolker, Shmuel Carmeli, \\ Maggie Levy, Christopher D. Skory, Amnon Lichter, and Dani Eshel
}

First, second, third, fourth, fifth, ninth, and tenth authors: Department of Postharvest Sciences of Fresh Produce, The Agricultural Research Organization (ARO), The Volcani Center, Bet-Dagan, Israel; second, third, and seventh authors: Department of Plant Pathology and Microbiology, The Robert H. Smith Faculty of Agriculture, Food and Environment, The Hebrew University of Jerusalem, Rehovot, Israel; sixth author: Department of Chemistry, Tel Aviv University, Tel Aviv, Israel; and eighth author: Renewable Product Technology Research Unit, NTL Center for Agricultural Utilization Research, Peoria, IL.

Accepted for publication 17 September 2013.

\begin{abstract}
Turgeman, T., Kakongi, N., Schneider, A., Vinokur, Y., Teper-Bamnolker, P., Carmeli, S., Levy, M., Skory, C. D., Lichter, A., and Eshel, D. 2014. Induction of Rhizopus oryzae germination under starvation using host metabolites increases spore susceptibility to heat stress. Phytopathology 104:240-247.

Sweetpotato is a nutritional source worldwide. Soft rot caused by Rhizopus spp. is a major limiting factor in the storage of produce, rendering it potentially unsafe for human consumption. In this study, Rhizopus oryzae was used to develop a concept of postharvest disease control by weakening the pathogen through induction of spore germination under starvation conditions. We isolated the sweetpotato active

dose to enhance spore weakening caused by starvation. Germination in SPAF at $1 \mathrm{mg} / \mathrm{ml}$ weakened the pathogen spores by delaying their ability to form colonies on rich media and by increasing their sensitivity to heat stress. The weakening effect was also supported by reduced metabolic activity, as detected by Alarmar Blue fluorescent dye assays. Spores incubated with SPAF at $1 \mathrm{mg} / \mathrm{ml}$ showed DNA fragmentation in some of their nuclei, as observed by TUNEL assay. In addition, these spores exhibited changes in ultrastructural morphology (i.e., shrinkage of germ tubes, nucleus deformation, and vacuole formation) which are hallmarks of programmed cell death. We suggest that induction of spore germination under starvation conditions increases their susceptibility to stress and, therefore, might be considered a new strategy for pathogen control.
\end{abstract} fractions (SPAFs) that induce spore germination and used them at a low
A wide range of microbial pathogens contaminate fresh and processed foods during postharvest handling and storage. Of these, fungal pathogens are a major threat to fruit and vegetables. The source of these pathogens is usually the field or the handling and storage environments $(2,3,8,13,30,31)$. In most cases, nongerminated dormant fungal spores, which are relatively resistant to abiotic stress, can be found in large quantities on the surface of the agricultural product and in the storage facility. Spore germination marks the transition from dormant to active stage and, therefore, is of critical importance to pathogenicity. The spore-germination process goes through three to four stages: (i) breaking of spore dormancy, (ii) isotropic swelling, (iii) establishment of cell polarity, and (iv) formation of a germ tube and maintenance of polar growth $(7,35)$. Although these stages may vary considerably among fungal species, the essential feature of a shift from low to high metabolic activity (inactive to active phase) is the hallmark of this transition (15).

In some fungi, spore germination is induced by hydration, whereas in others it is induced by hydrophobic surfaces, simple sugars, or minerals (19). Wound-invading necrotrophic fungi such as Rhizopus oryzae, Penicillium expansum, and Botrytis cinerea require nutrients which often originate from host wounds to induce spore germination (20). In sweetpotato, germination and growth of $R$. oryzae is naturally induced by compounds released

Corresponding author: D. Eshel; E-mail address: dani@volcani.agri.gov.il

* The $\boldsymbol{e}$-Xtra logo stands for "electronic extra" and indicates that Figure 5 appears in color online.

http://dx.doi.org/10.1094/PHYTO-08-13-0245-R

(C) 2014 The American Phytopathological Society from storage roots (4). In general, compounds involved in the induction of spore germination are carbohydrates and amino acids which provide the exogenous carbon and nitrogen, respectively, required for spore germination (24).

In vitro studies have shown that, for some fungi, the nutrient composition can be of critical importance. When only some of the components are present, the spores can initiate germination but subsequent unknown processes can lead to loss of viability or cell death $(10,18,32,36)$. For example, $2 \%$ glucose induced DNA fragmentation, production of reactive oxygen species, cell shrinkage, loss of intracellular structure, membrane damage, and nuclear condensation in yeast, whereas the addition of a nitrogen source can prevent this cascade $(17,18)$. Carbon starvation is associated with cell-wall degradation and autolysis in Aspergillus nidulans (11). In addition, programmed cell death (PCD) and apoptosislike events have also been described in filamentous fungi under carbon starvation $(10,12,26)$. Nitrogen starvation has also been associated with PCD involving massive changes in gene expression (1).

Rhizopus soft rot is a destructive and widespread postharvest disease of sweetpotato worldwide caused by the Rhizopus spp. $R$. stolonifer, also known as the common bread mold, and $R$. oryzae $(5,19,25,29)$. The disease involves rapid development of watery soft rot of the internal portion of the storage root, with the periderm generally remaining intact $(6,27)$. Once infection has occurred, the pathogen causes biochemical changes through the secretion of enzymes and metabolites that cause tissue breakdown (4). It takes a few days for the entire storage root to rot but the rate of decay depends on the fungal species, the sweetpotato cultivar, and the storage conditions. In susceptible cultivars, $R$. stolonifer can decompose an entire storage root in 3 to 4 days 
at $15^{\circ} \mathrm{C}(19,27)$. When the periderm or skin of the soft, watery tissue ruptures, the molds can spread to healthy storage roots, thus increasing disease incidence.

Constant efforts to gain control of microbial attack of fresh fruit and vegetables often give unsatisfactory results or do not comply with regulatory and environmental sustainability, human health, or both. In this study, we isolated the soluble sweetpotato compound that induces $R$. oryzae spore germination with the aim of using it to increase spore susceptibility to heat stress.

\section{MATERIALS AND METHODS}

Fungal strains, culture conditions, and storage of fungal strains. $R$. oryzae isolate A1 (GenBank: JN543964.1) used in this study was isolated from sweetpotato storage roots expressing the typical disease symptoms of Rhizopus soft rot. Cultures were routinely grown at $25^{\circ} \mathrm{C}$ on potato dextrose agar (PDA) plates, which was found to be the optimal temperature for proliferation of the A1 strain (data not shown). PDA was prepared by dissolving $39 \mathrm{~g}$ of PDA powder (Difco, Detroit, MI) and $25 \mathrm{mg}$ of chloramphenicol (Sigma, Israel) in 1 liter of purified water, sterilizing it in an autoclave, and pouring the medium into $90-\mathrm{mm}$ petri dishes. For genomic DNA experiments, fungal cultures were grown in potato dextrose broth (PDB; Difco) prepared by dissolving $40 \mathrm{~g}$ of PDB powder and $25 \mathrm{mg}$ of chloramphenicol in 1 liter of purified water followed by sterilization of $100-\mathrm{ml}$ aliquots in 250-ml Erlenmeyer flasks. Growth was carried out at $28^{\circ} \mathrm{C}$ and $130 \mathrm{rpm}$ in an orbital shaker incubator. A solution of $5 \times 10^{5}$ spores $/ \mathrm{ml}$ in $25 \%$ glycerol was kept in 2-ml tubes at $-80^{\circ} \mathrm{C}$. Fresh cultures were started by placing $20 \mu \mathrm{l}$ of fungal stock in the center of a PDA plate.

Extraction of sweetpotato juice and active compound. 'Georgia Jet' sweetpotato (Ipomoea batatas L.) storage roots were grown in sandy soil in the northwestern Negev desert, in the south of Israel $\left(31^{\circ} 25^{\prime} \mathrm{N}, 34^{\circ} 29^{\prime} \mathrm{E}\right.$, elevation 50 to $\left.150 \mathrm{~m}\right)$ in 2008 to 2012 and stored in a cold room $\left(14^{\circ} \mathrm{C}, 95 \%\right.$ relative humidity). The storage roots were peeled and $1 \mathrm{~kg}$ of flesh was homogenized with a food processor. The soluble sweetpotato juice extract (SPJE) was further purified by filtration through eight layers of gauze cloth followed by centrifugation at $12,000 \times g$ for $10 \mathrm{~min}$ in a Sorvall centrifuge. The soluble part of the SPJE was extracted twice by phase separation using chloroform (1:2 ratio, vol/vol) and the aqueous layer was boiled and centrifuged as above to remove denatured proteins. The supernatant was filtered through $0.45-\mu m$ Millex-HV filter (Millipore SA, Belgium) and passed through a C18 solid-phase extraction cartridge (Sep-Pak C18; Waters, Inc., Milford, MA) according to the manufacturer's guidelines. The effluent was frozen and lyophilized (Alpha 1-2; Christ, Osterode, Germany) for $24 \mathrm{~h}$. Finally, the lyophilized powder $(\approx 50 \mathrm{~g})$ was suspended in double-distilled water and termed sweetpotato active fraction (SPAF).

To characterize the different compounds in the SPAF, ultrafast liquid chromatography (UFLC) was carried out using an LC-10A UFLC system with a SIL-HT automatic sample injector, a UV/VIS detector (SPD-20A), and automatic fraction collector (FRC-10A) (Shimadzu, Japan). In addition, the UFLC was equipped with a differential refractometer detector (Waters model 410) and SugarPak I column (Waters Associates). The mobile phase (ultrapurified deionized water) was eluted through the system for $30 \mathrm{~min}$ at a flow rate of $0.5 \mathrm{ml} / \mathrm{min}$ and column temperature was set to $80^{\circ} \mathrm{C}$.

Bioassay for the germination pattern induced by SPAF using Rhizopus spores. To study the germination pattern of fungal spores induced by SPAF, we examined the spores at various time points during incubation following treatment. Spores were harvested from 1- to 2-week-old PDA plates by gently rubbing the mycelia with a Drigalski spatula and sterile water. The suspension was filtered through eight layers of gauze cloth and spore con- centration was determined by counting in a hemacytometer with a light microscope; the concentration was adjusted to the desired value by adding sterile water. Fungal spores were incubated in sterile water: SPJE $(10 \%)$ or SPAF $(1,5,10,20$, and $50 \mathrm{mg} / \mathrm{ml}$ in water). The treated spores (final concentration of $5 \times 10^{5}$ spores/ $\mathrm{ml}$ ) were then incubated in an orbital shaker at $30^{\circ} \mathrm{C}$ and $100 \mathrm{rpm}$. Spore germination was examined after $3 \mathrm{~h}$ and then every $60 \mathrm{~min}$ by mixing the solution and placing a drop of $10 \mu \mathrm{l}$ (in duplicate) onto a glass slide and observing it under a light microscope. For photography, $1 \mathrm{ml}$ of the sample at each time point was spun down $\left(4^{\circ} \mathrm{C}, 2,500 \times g\right)$ and the spores were fixed in $3.7 \%$ formaldehyde to prevent further growth. Images were taken with a Nikon DS-Fildigital camera. The germ tubes were measured at their maximal diameter using the ImageJ program (http://rsbweb. nih.gov/ij/). The experiment was repeated independently at least three times.

Scanning electron microscopy and transmitted light electron microscopy. To characterize the external morphological changes induced by SPAF, the spores were analyzed by scanning electron microscopy (SEM). Four hours after germination induction, the samples were washed twice with water and fixed with $2.5 \%$ glutaraldehyde on $0.6-\mu \mathrm{m}$ membrane filters (Nuclepore Corp., Pleasanton, CA). The spores were dried in a critical-point drier, sputter coated with gold, and observed under a scanning electron microscope (JEOL JSM-840A). Treatment and fixation were repeated twice and more than three images were taken from each treatment and object. The selected images are representative of the effect of the treatment. Transmitted light electron microscopy (TEM) was carried out on germinated spores fixed with $2.5 \%$ glutaraldehyde for $24 \mathrm{~h}$ at room temperature. The specimens were washed three times with $1 \mathrm{M}$ phosphate buffered saline (PBS) ( $\mathrm{pH} \mathrm{7.2)} \mathrm{for} 15 \mathrm{~min}$ each, and post-fixed in reduced osmium tetroxide $\left(1 \% \mathrm{OsO}_{4}\right)$ for $2 \mathrm{~h}$ at room temperature. The specimens were dehydrated in increasing ethanol concentrations and embedded in glycid ether 100 (Serva, Heidelberg, Germany). Sections (40 to $60 \mathrm{~nm}$ ) were cut with a Leica Ultracut RM2265, stained with lead citrate (number 15326; Sigma) and uranyl acetate (number 73943; Sigma), and examined with a JEOL $\mathrm{H}-7650$ transmission electron microscope.

Histological analysis for DNA fragmentation by TUNEL assay and 4',6-diamidino-2-phenylindole staining. Histological analysis to detect DNA fragmentation in germinated spores of Rhizopus strains was performed on spores incubated in SPJE or SPAF. The samples were stained according to the method described by Teper-Bamnolker et al. (33), with some modifications. For terminal deoxynucleotidyltransferase-mediated dUTP nick end labeling (TUNEL) detection (14), samples fixed in $3.7 \%$ formalin-acetic acid-alcohol (Sigma) were washed twice with PBS. For cell-wall lysis, samples were incubated with enzyme mixture (0.1 g each of lysing enzyme [number L1414; Sigma], cellulase [number 22178; Fluka, Hamburg, Germany], and yatalase [number T017; Takara, Shiga, Japan] dissolved in $15 \mathrm{ml}$ of osmotic medium [10 $\mathrm{mM} \mathrm{Na}_{2} \mathrm{HPO}_{4}$ and $\mathrm{MgSO}_{4}$ at $157.9 \mathrm{~g} /$ liter]) on an ST-600 orbital shaker at $4^{\circ} \mathrm{C}$ and $50 \mathrm{rpm}$ for $6 \mathrm{~h}$. The enzyme/lysing solution was filtered through a $0.45-\mu \mathrm{m}$ Millipore filter and $5 \mathrm{ml}$ of this solution was added to each treatment sample before overnight incubation at $27^{\circ} \mathrm{C}$ and $50 \mathrm{rpm}$. A trapping buffer $(5 \mathrm{ml})$ was added to the samples in glass tubes (Corex) to pull down debris or residues at $2,655 \times g$ for $15 \mathrm{~min}$. Then, 2 to 2.5 volumes of STC (1 M sorbitol, $10 \mathrm{mM}$ Tris [pH 7.5], and $10 \mathrm{mM} \mathrm{CaCl}$ ) was added to the supernatants in $15-\mathrm{ml}$ tubes and the cells were spun down at $2,700 \times g$ for $15 \mathrm{~min}$. The germinating spores were washed twice with PBS before treatment with permeabilization solution $(0.5 \%$ Triton $\mathrm{X}-100$ and $0.1 \%$ sodium citrate in purified water) and incubated for $2 \mathrm{~min}$ on ice. The germinating spores were washed again twice with PBS before staining. TUNEL reaction was performed in 1.5-ml tubes using the In Situ Cell Death Detection Kit with fluorescein 
(Roche Applied Science, Mannheim, Germany), according to the manufacturer's instructions. To visualize nuclei in treated spores, samples were stained with 4'-6-diamidino-2-phenylindole (DAPI) (Sigma) at $1 \mu \mathrm{g} / \mathrm{ml}$ in PBS buffer for $20 \mathrm{~min}$. DAPI and TUNELpositive staining were observed with an Olympus IX81/FV500 confocal laser-scanning microscope equipped with a 488-nm argon ion laser and 405-nm diode laser. DAPI was excited with the 405-nm diode laser and the emission was collected through a barrier filter of 430- to 460-nm. Flourescein was excited at 488 $\mathrm{nm}$ and the emission was collected through a BA505IF filter. The transmitted light images were obtained using Nomarski differential interference contrast, and three-dimensional images were obtained using the FluoView 500 software supplied with the confocal laser-scanning microscope.

Sensitivity of germinating spores to heat shock. To determine the sensitivity of treated spores to heat shock as an external stress, we determined their ability to form colonies upon heat treatment. The spores were harvested and incubated to germination as described above. The spores, in the presence of SPAF, SPJE or water and at a concentration of $5 \times 10^{5}$ spores $/ \mathrm{ml}$, were then exposed to heat treatment in $0.2-\mathrm{ml}$ tubes on a gradient polymerase chain reaction block (Biometra, Gottingen, Germany). The temperature was set to $42^{\circ} \mathrm{C}$ and the exposure times were 0 (control), $5,10,15,20,25,35$, and $45 \mathrm{~min}$. Immediately after heat treatment, $50 \mu \mathrm{l}$ of each sample was cultured on a PDA plate and incubated overnight at $25^{\circ} \mathrm{C}$. The number of colonies (maximal number $=150$ ) formed for each exposure time were counted and compared with those of controls (zero exposure time) and results were expressed as percentage of developing colonies. The overall time course experiment was repeated independently three times.

Mitochondrial respiration measurements. To follow the effects of different concentrations of SPAF on mitochondrial activity and cellular proliferation of Rhizopus strains, we used the fluorescent dye Alamar Blue (AbDSerotec, Oxford, UK). Alamar Blue is a redox indicator of cell proliferation and has not been found to interfere with reactions or metabolic activities within cells (28). In this assay, the greater the metabolic activity in the spore, the greater the level of oxidation of Alamar Blue and the greater the fluorescence. Spores were incubated in SPJE, SPAF, or water for $5 \mathrm{~h}$ at $25^{\circ} \mathrm{C}$. Incubated spores were washed twice with PBS and resuspended in $100 \mu \mathrm{l}$ of buffer, then treated with $100 \mu \mathrm{l}$ of malt extract and $20 \mu \mathrm{l}$ of Alamar Blue fluorescent dye in a 96-well plate. Fluorescence was monitored using a plate reader (EnSpire 2300; Perkin Elmer, Fremont, CA) at excitation and emission wavelengths of 530 and $590 \mathrm{~nm}$, respectively. The redox

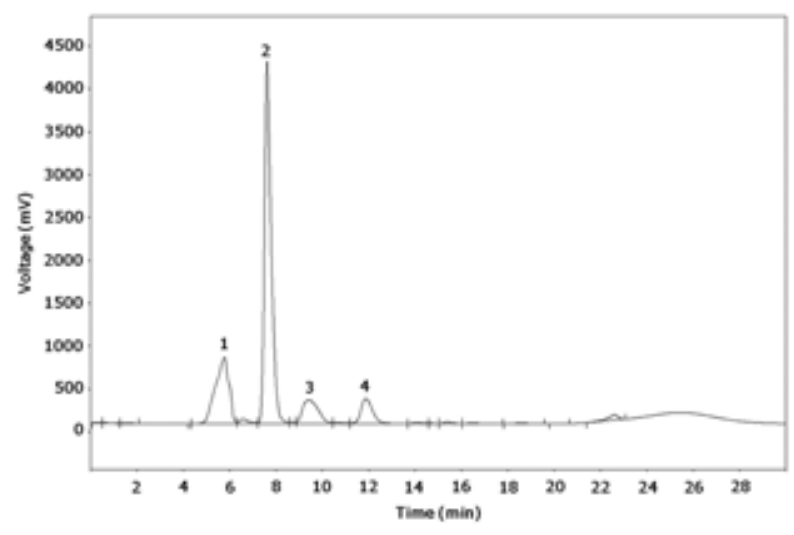

Fig. 1. Liquid chromatography separation of sweetpotato active fraction using cation-exchange column. Four major peaks were observed by refractive index detection at the retention times of 5.5, 7.8, 9.6, and 11.8 min (peaks 1 to 4 , respectively). Peak 1 found as a mixture of organic acids and amino acids. Peaks 2 to 4 had the same retention times as purified standards of sucrose, glucose, and fructose, respectively. potential of the spores was measured hourly for $6 \mathrm{~h}$. The experiment was repeated three times.

Statistical analysis. Each experiment was repeated at least three times, and the data were analyzed with JMP software. Treatment means were compared by least significant difference using one-way analysis of variance $(P<0.05)$.

\section{RESULTS}

Extraction, purification, and characterization of SPAF. Initial colonization of $R$. oryzae spores occurs in the parenchyma of the sweetpotato storage root. To isolate potential inducers of spore germination from this tissue, a crude extract was prepared, followed by extractions with chloroform and passage through a C18 cartridge. After each extraction step, the fractions were subjected to spore-germination assays. Spore germination was consistently induced when $R$. oryzae spores were exposed to the polar phase of all extracts. After these purification steps, the extract was lyophilized to a fine white powder and termed SPAF. When dissolved in water, SPAF had a $\mathrm{pH}$ of 4.7. Solutions with the same $\mathrm{pH}$ (titrated by $\mathrm{HCl}$ or acetic acid) did not induce spore germination (data not shown). Separation of SPAF on an analytical cation-exchange column revealed four major peaks with maximal absorbance at the retention times of 5.5, 7.8, 9.6, and $11.8 \mathrm{~min}$ (Fig. 1; peaks 1 to 4 , respectively). Gas chromatography-mass spectrometry analysis revealed impurity of peak 1 , comprising mainly organic acids and amino acids (not shown). Peaks 2 to 4 were identified as sucrose, glucose, and fructose, respectively, according to the retention times of standards (numbers S7903, G8270, and F0127, respectively) (Sigma). Any attempt to induce germination with the purified peaks resulted in loss of activity (data not shown), suggesting that the combination of compounds present in the juice is essential to induce germination.

Effect of SPAF on $R$. oryzae spore germination. Because the SPAF fraction was found to contain mainly nutritional ingredients, we looked for a minimal SPAF concentration that would only induce spore germination followed by starvation conditions. $R$. oryzae spores were incubated with several SPAF concentrations and the effect on germination percentage, spore diameter, and germ-tube diameter was determined (Fig. 2; Table 1). Elevated SPAF concentrations increased the percentage and accelerated the rate of spore germination (Table 1). Four hours after SPAF incubation, spore germination was observed in all treatments. Maximal activity was recorded in the SPAF and SPJE incubations at $20 \mathrm{mg} / \mathrm{ml}(57.1$ and $54.7 \%$ germination, respectively). With SPAF at 10,5 , and $1 \mathrm{mg} / \mathrm{ml}$, spore germination decreased (34.6, 24.3, and $17.5 \%$, respectively), and its highest rate was observed with SPAF and SPJE incubations at $20 \mathrm{mg} / \mathrm{ml}$ $6 \mathrm{~h}$ after induction (97.5 and $98.0 \%$, respectively). At the lower SPAF concentrations, maximal spore germination was observed $8 \mathrm{~h}$ after induction $(97.3,94.3$, and $72.9 \%$ in 10,5 , and $1 \mathrm{mg} / \mathrm{ml}$, respectively). No significant difference was found between the effects of SPAF at 20 and $50 \mathrm{mg} / \mathrm{ml}$ on spore germination rate (not shown).

Low SPAF concentration induced germination with reduced spore swelling (Fig. 2A and B). Spore diameter was $14.6 \pm 0.5$, $18.1 \pm 0.5,19.6 \pm 0.5$, and $20.8 \pm 0.4 \mu \mathrm{m} 5 \mathrm{~h}$ after the addition of SPAF at $1,5,10$, and $20 \mathrm{mg} / \mathrm{ml}$, respectively. No significant difference in spore diameter was found between incubation in SPAF or SPJE at 20 and $50 \mathrm{mg} / \mathrm{ml}$ (Fig. 2B). The average diameter of the nonswelling spores in the water control incubation was $8.6 \mu \mathrm{m}$ and it did not change during $8 \mathrm{~h}$ of observation.

Germ-tube diameter was also affected by the SPAF concentrations. Germ-tube diameter was $2.5 \pm 0.1,4.0 \pm 0.2,4.9 \pm 0.1$, and $6.0 \pm 0.3 \mu \mathrm{m} 8 \mathrm{~h}$ after addition of SPAF at 1, 5, 10, and $20 \mathrm{mg} / \mathrm{ml}$, respectively (Fig. 2C). Similar to the data on spore germination, no significant differences were observed in germ- 
tube diameter between the incubations with SPAF or SPJE at 20 and $50 \mathrm{mg} / \mathrm{ml}$ (both $6.5 \pm 0.2 \mu \mathrm{m}$ ). Taken together, these results suggest that addition of SPAF at $1 \mathrm{mg} / \mathrm{ml}$ to spores can induce germination but is insufficient for expression of the spores' full developmental potential.

To investigate whether the abnormal development caused by incubation with a low concentration of SPAF is reversible, an additional supplement of SPJE was added to the primary hyphae after $7 \mathrm{~h}$ of SPAF incubation. $R$. oryzae germ-tube diameter decreased significantly with time from 4.0 to 3.3 and $2.5 \mu \mathrm{m}$ at 6 , 7 , and $8 \mathrm{~h}$, respectively, after addition of SPAF at $1 \mathrm{mg} / \mathrm{ml}$ (Fig. $3 \mathrm{~A}$ and $\mathrm{B}$ ). Addition of SPJE stopped germ-tube shriveling and, $1 \mathrm{~h}$ later, germ-tube diameter increased to $4.8 \mu \mathrm{m}$. Interestingly, addition of SPJE caused swelling of the tip of the germ tube but not its other part (Fig. 3A, marked with an arrow). In the SPAF incubation at $10 \mathrm{mg} / \mathrm{ml}$, addition of SPJE caused uniform swelling along the axis of the germ tube whereas, with SPAF incubation at $20 \mathrm{mg} / \mathrm{ml}$, addition of SPJE had no effect on hyphal swelling.

Stress symptoms associated with a low dose of SPAF. The effects of low SPAF concentration on the cellular ultrastuctural and external morphology of the germinating spores were examined by TEM and SEM (Fig. 4). Sections through the swelling spores revealed structural deformation of the organelles with the low dose of SPAF $(1 \mathrm{mg} / \mathrm{ml})$ compared with SPJE-incubated spores. The nuclei of the SPJE-incubated spores (Fig. 4, marked with an arrow) had a regular symmetrical round shape, with a darker region representing the nucleolus. In contrast, the SPAFincubated spores exhibited bright and asymmetrical shapes for both nucleus and nucleolus. In addition, large vacuoles were observed in the SPAF- but not SPJE-incubated spores. The external view by SEM showed a normal wrinkled surface appearance (gently curved spore contours) for the germ tubes of SPJEincubated spores, whereas spores incubated with SPAF at $1 \mathrm{mg} / \mathrm{ml}$ had a smooth surface. Another interesting feature was the dark spots observed in the germ tubes of SPAF-incubated but not SPJE-incubated spores, which might be vacuoles (Fig. 4E, marked with an arrow).

To determine whether SPAF at $1 \mathrm{mg} / \mathrm{ml}$ induces apoptotic processes, a TUNEL assay was performed to detect DNA fragmentation in the spores. The nuclei in the germ tubes of SPAFincubated spores emitted green fluorescein, whereas no labeling was detected in the SPJE-incubated spores (Fig. 5). This result suggested that SPAF spores undergo a process of DNA fragmentation after starvation stress.

To confirm the weakening effect of the incubation with SPAF at $1 \mathrm{mg} / \mathrm{ml}$, the spores' metabolic activity was determined by Alamar Blue assay. The results showed that, $2 \mathrm{~h}$ after adding Alamar Blue to the spores, there was a significant decrease in the fluorescence of SPAF-incubated spores $(1 \mathrm{mg} / \mathrm{ml})$ compared with SPJE-incubated spores (Fig. 6). This difference was maintained for up to
A

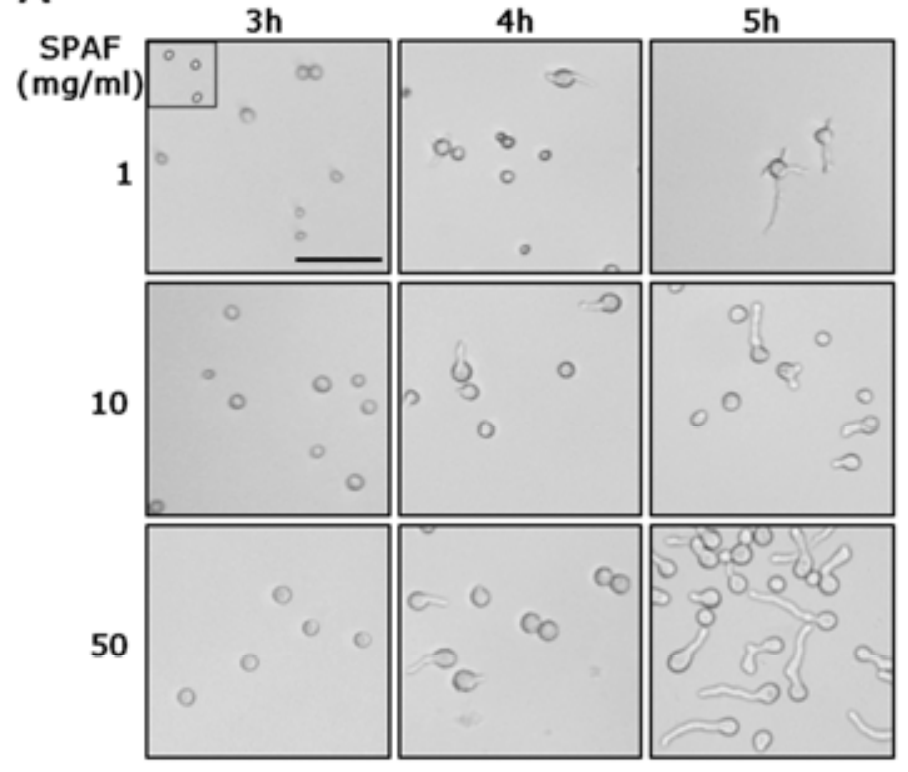

B
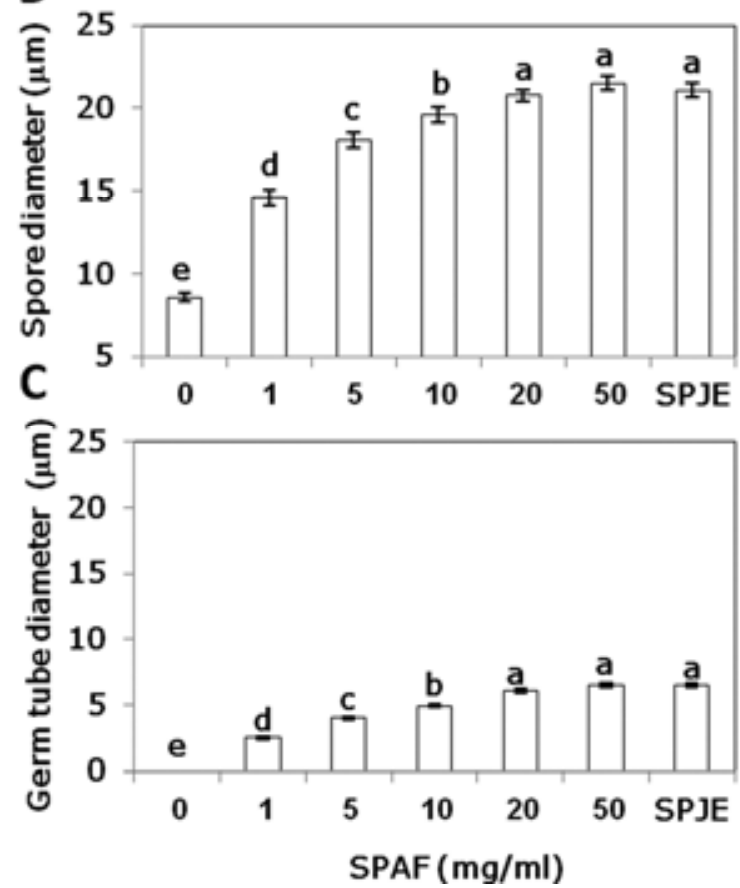

Fig. 2. Dose response of Rhizopus oryzae spores to sweetpotato active fraction (SPAF) compared with sweetpotato juice extract (SPJE). A, Micrographs of spores after different incubation intervals (inset shows water-incubated spores, bar $=100 \mu \mathrm{m}$ ). B, Spore diameter after $5 \mathrm{~h}$ of incubation. C, Germ-tube diameter after $8 \mathrm{~h}$ of incubation. Values are means \pm standard error $(n=100)$. Different lowercase letters above the bars denote significant differences $(P<0.05)$.

TABLE 1. Germination percentage of Rhizopus oryzae spores incubated in different concentrations of sweetpotato active fraction (SPAF) or sweetpotato juice extract (SPJE)

\begin{tabular}{lccccc}
\hline & \multicolumn{5}{c}{ SPAF $(\mathrm{mg} / \mathrm{ml})^{\mathrm{z}}$} \\
\cline { 2 - 6 } Time $(\mathrm{h})$ & 1 & 5 & 10 & $54.7 \pm 3.1 \mathrm{a}$ & SPJE \\
\hline 4 & $17.5 \pm 1.2 \mathrm{~d}$ & $24.3 \pm 1.3 \mathrm{c}$ & $34.6 \pm 1.5 \mathrm{~b}$ & $57.1 \pm 0.7 \mathrm{a}$ & $81.1 \pm 0.7 \mathrm{a}$ \\
5 & $37.9 \pm 3.9 \mathrm{c}$ & $54.6 \pm 0.9 \mathrm{~b}$ & $79.9 \pm 2.2 \mathrm{a}$ & $82.6 \pm 0.5 \mathrm{a}$ & $97.5 \pm 1.0 \mathrm{a}$ \\
6 & $54.1 \pm 2.1 \mathrm{e}$ & $73.6 \pm 1.4 \mathrm{~d}$ & $83.5 \pm 1.8 \mathrm{c}$ & $98.0 \pm 0.4 \mathrm{~b}$ & $98.7 \pm 0.9 \mathrm{a}$ \\
7 & $70.7 \pm 2.3 \mathrm{~d}$ & $84.2 \pm 0.5 \mathrm{c}$ & $90.6 \pm 0.4 \mathrm{~b}$ & $98.8 \pm 0.5 \mathrm{a}$ & $99.2 \pm 0.3 \mathrm{a}$ \\
8 & $72.9 \pm 0.6 \mathrm{c}$ & $94.3 \pm 1.9 \mathrm{~b}$ & $97.3 \pm 0.5 \mathrm{~b}$ & $98.3 \pm 1.6 \mathrm{ab}$ & \\
\hline
\end{tabular}

${ }^{\mathrm{z}}$ Means ( \pm standard error) followed by different lowercase letters are significantly different $(P<0.05)$. 
A

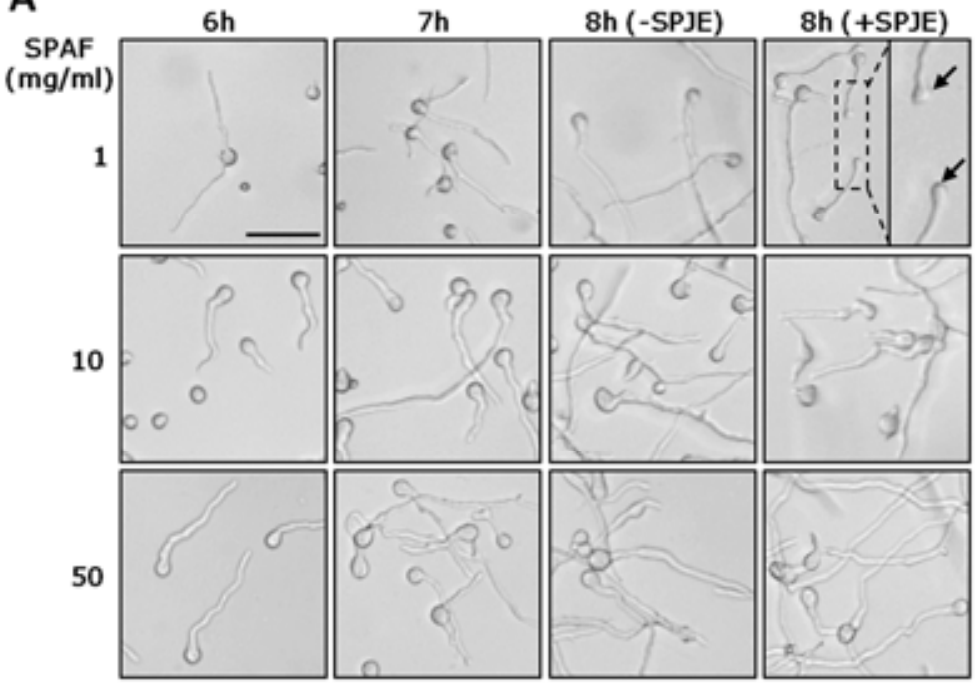

B

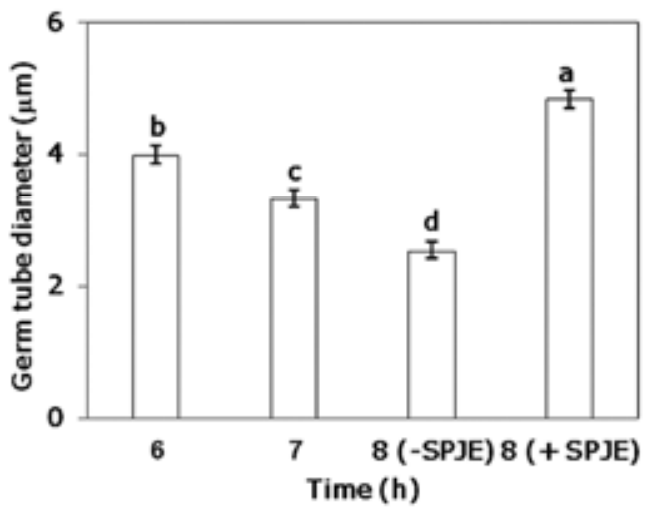

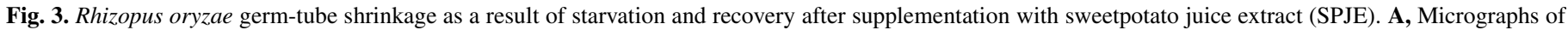

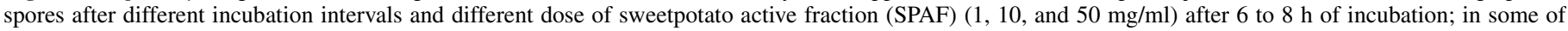

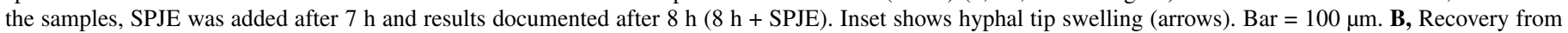

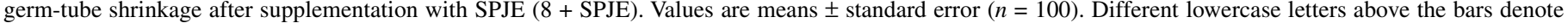
significant differences $(P<0.05)$.
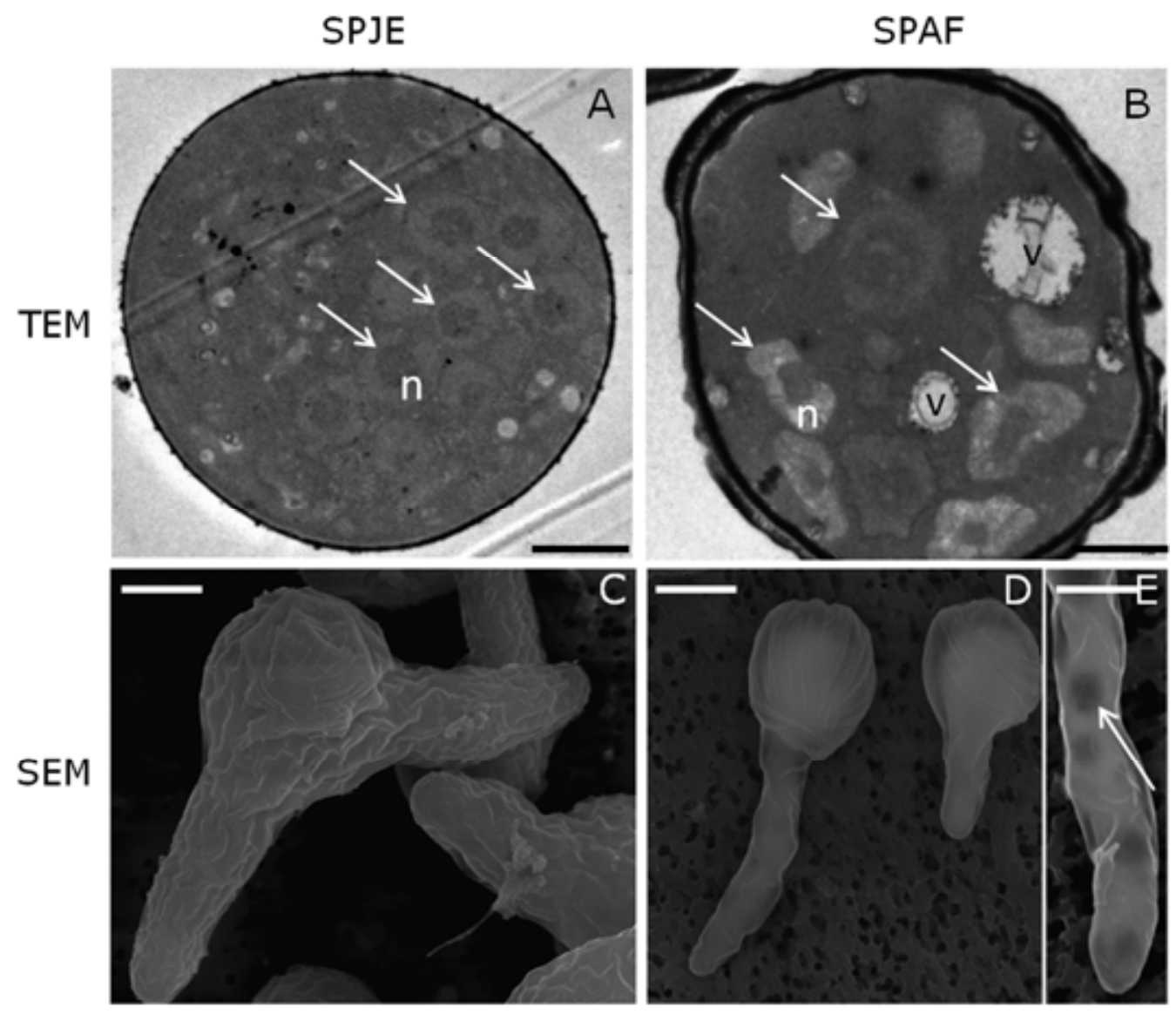

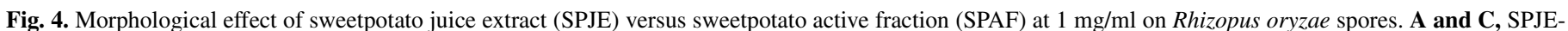

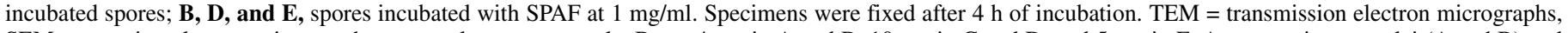

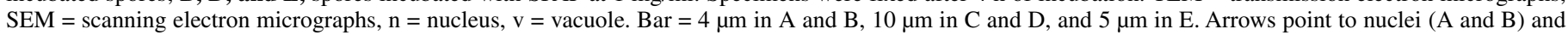
vacuoles $(\mathrm{E})$.

$6 \mathrm{~h}$. Water-incubated spores maintained low metabolic activity, as expected.

Spore sensitivity to heat shock after SPAF incubation. The effect of a low dose of SPAF on spore germination, together with the observed deformation of cell organelles, DNA fragmentation, and a reduction in metabolic activity, suggested that the incubated spores would be more susceptible to stress. This hypothesis was tested by applying mild heat stress after incubation with SPAF at $1 \mathrm{mg} / \mathrm{ml}$, SPJE, or water and measuring spore recovery as expressed by colony formation on PDA plates. Various temperatures 

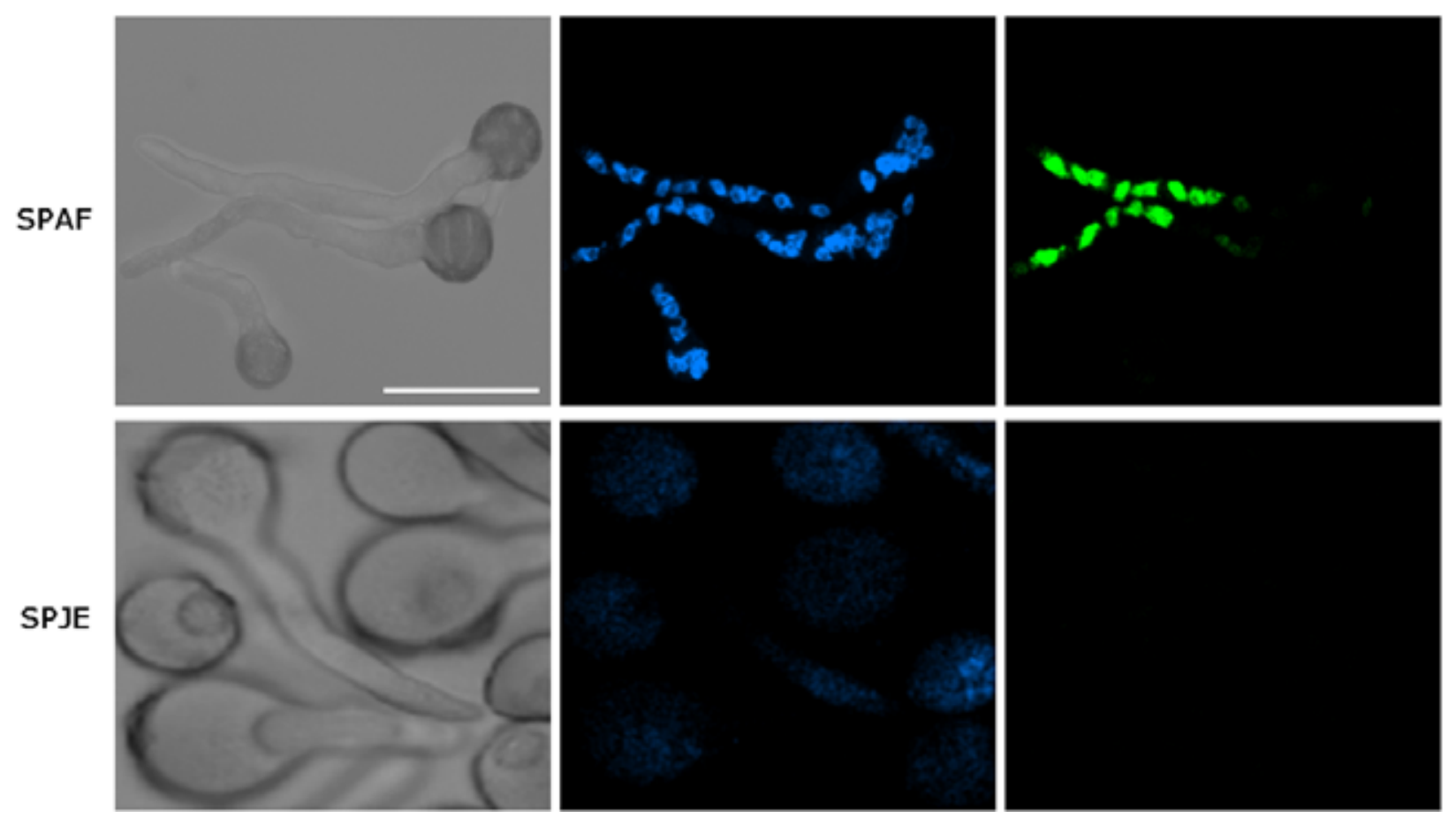

Fig. 5. DNA fragmentation induced in Rhizopus oryzae spores after incubation in sweetpotato active fraction (SPAF) at $1 \mathrm{mg} / \mathrm{ml}$. Specimens were fixed after $4 \mathrm{~h}$ of incubation followed by 4'-6-diamidino-2-phenylindole (DAPI) staining and terminal deoxynucleotidyltransferase-mediated dUTP nick end labeling (TUNEL) detection. DAPI emission was observed in both treatments, while cleaved DNA end-labeled with fluorescein dUTP was detected only in the spores treated with $\mathrm{SPAF}$ at $1 \mathrm{mg} / \mathrm{ml}$. SPJE $=$ sweetpotato juice extract. $\mathrm{PhC}=$ Phase contrast. $\mathrm{Bar}=20 \mu \mathrm{m}$.

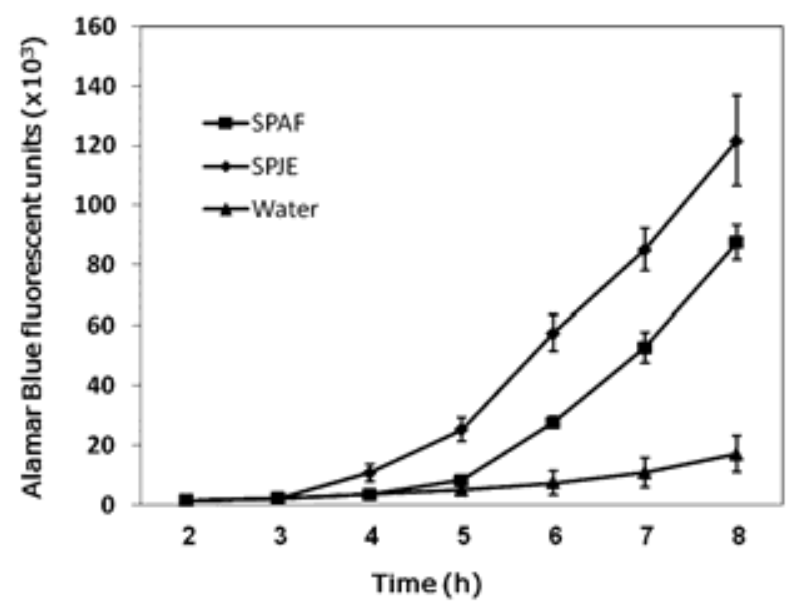

Fig. 6. Effect of sweetpotato active fraction (SPAF) on metabolic activity of Rhizopus oryzae spores. Alamar Blue fluorescence was measured upon incubation in SPAF at $1 \mathrm{mg} / \mathrm{ml}$, sweetpotato juice extract (SPJE), or water. Values are means \pm standard error $(n=3)$.

of 25 to $50^{\circ} \mathrm{C}$ were first applied (data not shown) and $42^{\circ} \mathrm{C}$ was chosen for the time-course analysis (Fig. 7). For the first 15 min of exposure to heat, there was no significant difference in colony formation between the SPAF, SPJE, and water incubations. Spores incubated with SPAF at $1 \mathrm{mg} / \mathrm{ml}$ showed a decline in colony formation after $15 \mathrm{~min}$ of exposure to heat stress, whereas SPJE-incubated spores declined only after $25 \mathrm{~min}$. After $35 \mathrm{~min}$ of heat stress, only $4.6 \%$ of the SPAF-incubated spores had survived, whereas SPJE-incubated spores showed approximately $58.4 \%$ survival. After 45 min of heat stress, spores incubated in $\mathrm{SPAF}$ at $1 \mathrm{mg} / \mathrm{ml}$ completely failed to form colonies, whereas incubation in SPJE and water resulted in the survival of 46 and $100 \%$ of the spores, respectively.

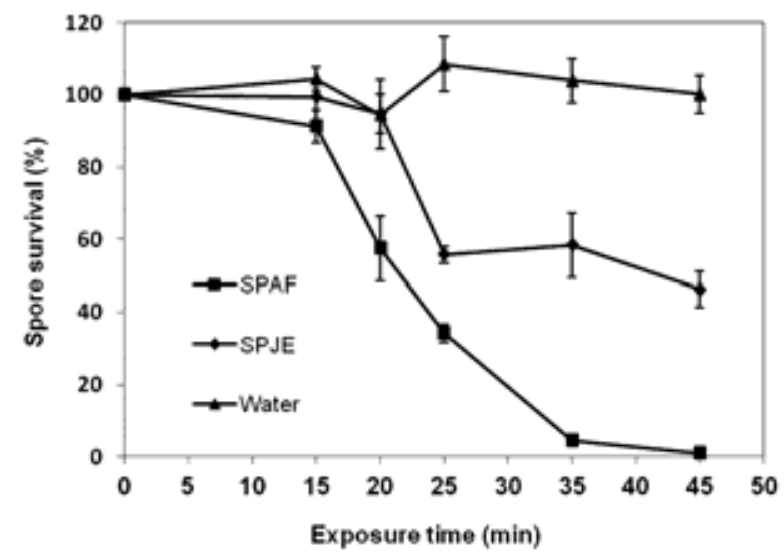

Fig. 7. Percentage of spores that formed colonies on agar after heat shock; colony formation after heat shock $\left(42^{\circ} \mathrm{C}\right)$, following incubation in sweetpotato active fraction (SPAF) at $1 \mathrm{mg} / \mathrm{ml}$, sweetpotato juice extract (SPJE), or water. Values are means \pm standard error $(n=3)$.

\section{DISCUSSION}

The long-term goal of this study was to develop a concept of disease control through weakening of a pathogenic fungus by inducing its germination under starvation conditions. This may be facilitated by the use of host-derived nutrients that induce spore germination. A semipurified extract of SPAF was isolated from the host juice according to its ability to induce germination of $R$. oryzae spores. SPAF was identified as a mixture of mainly organic acids, amino acids, and carbohydrates (Fig. 1). The combination of these compounds induced swelling and germination of $R$. oryzae spores (Figs. 2A and 3A). These results are in agreement with previous reports discussing the ability of individual or a mixture of carbohydrates and amino acids in an acid environment $(\mathrm{pH} \approx 4)$ to induce germination of $R$. oryzae spores $(9,24,34)$. 
Once isolated, several doses of SPAF were tested to determine the lowest dose that would induce spore germination but would not fulfill the nutritional requirements of the developing hyphae. It was established that SPAF at $1 \mathrm{mg} / \mathrm{ml}$ induces germination of $R$. oryzae spores after $4 \mathrm{~h}$ of incubation (Fig. 2A), with development of thin germ tubes. The germination pattern was atypical in the sense that the spore did not fully swell prior to germ-tube emergence. In contrast, $R$. oryzae spores incubated in SPJE swelled and developed a thick germ tube resembling those in an earlier study (9). The results demonstrated that detection of a low concentration of nutrients by the dormant spore is sufficient to induce its germination, even though this amount of nutrient cannot support either normal spore swelling or subsequent hyphal development (Figs. 2B and 3B).

The lack of sufficient nutrients in the SPAF at $1 \mathrm{mg} / \mathrm{ml}$ incubation was reflected by hyphal shrinkage during the time-course experiment (Fig. 3). The hyphal deterioration could be reversed by supplementation of an additional nutrient source (10\% SPJE) to the incubation solution, where a significant increase in germtube diameter was measured $1 \mathrm{~h}$ after supplementation, accompanied by swelling of the germ-tube tip (Fig. 3A, arrows), probably due to rapid uptake of nutrients and water. Further examination is needed to determine whether this is a local response of the germ-tube tip.

$R$. oryzae spores germinating in a low nutrient environment (SPAF at $1 \mathrm{mg} / \mathrm{ml}$ ) were further examined by SEM and TEM (Fig. 4). SEM observation of the impaired hyphae revealed a number of features: (i) shrunken areas, (ii) transparency, (iii) smooth surface texture of the germ tubes and spores, and (iv) reduced germ-tube diameter. TEM observation revealed changes in the ultrastructural germ-tube morphology (i.e., nucleus deformation and vacuole formation) (Fig. 4B, marked with arrows and letter v, respectively). Cell shrinkage and vacuole formation have been reported as characteristic features of apoptotic cell death in various studies of yeast, $P$. expansum, and A. nidulans (16,21-23). Our observations are congruent with the hypothesis that starvation conditions, effected in this study by a low concentration of SPAF, induce apoptosis in $R$. oryzae. TUNEL assay results revealed green fluorescein emission indicating DNA fragmentation in the germ tubes of spores incubated in SPAF at $1 \mathrm{mg} / \mathrm{ml}$, which was not observed in the SPJE-incubated spores (Fig. 5), indicating that apoptotic processes are occurring in the primary hyphae under starvation conditions (14). In agreement with these results, a previous study showed that environmental stimuli such as nutrient deprivation, oxidative stress, and antifungal agents activate caspase-dependent and independent pathways linked to apoptotic changes in Aspergillus spp. (32).

From a functional point of view, the spores incubated in a low concentration of SPAF showed lower redox potential, as evident by Alamar Blue staining (Fig. 6), likely due to reduced mitochondrial activity (28). The reduction in mitochondrial activity might be due to the lack of nutrients accompanied by apoptotic processes (23), resulting in growth arrest and lower responsiveness to environmental stress. This hypothesis was tested by exposing the germinating spores to intermediate heat stress. The results of this assay clearly showed that the spores incubated in SPAF at $1 \mathrm{mg} / \mathrm{ml}$ were compromised in their ability to develop and form colonies after prolonged exposure to heat (Fig. 7). The weakening of the germinating spore, induced by SPAF, enables the use of mild heat stress as a stringency condition to reduce colony formation. We believe that, in practice, SPAF can be combined with higher-temperature treatment, allowing shortening of the exposure time.

The reduction in spore viability after exposure to conditions that facilitated germination but, at the same time, weakened the germinating spores creates an opportunity to use tools which are normally insufficient to control the pathogen. On the other hand, if the germinating spores encounter favorable conditions, they can switch to a viable and pathogenic mode more rapidly. We believe that spores do not stay dormant when they are exposed to injury, because the injury contains nutrients that induce fast germination. Sweetpotato storage roots are cured before storage, producing a closing layer over the exposed wound. Our control concept suggests the treatment of dormant spores, on the cured root, in order to reduce the probability of infection during storage or marketing by reducing the inoculum density. Combining with SPAF is expected to increase the efficiency of other control methods, such as heat treatment.

\section{ACKNOWLEDGMENTS}

This work was supported by the Chief Scientist, Ministry of Agriculture, Israel (430-421-12).

\section{LITERATURE CITED}

1. Abeliovich, H., and Klionsky, D. J. 2001. Autophagy in yeast: Mechanistic insights and physiological function. Microbiol. Mol. Biol. Rev. 65:463-479.

2. Beuchat, L. R. 2002. Ecological factors influencing survival and growth of human pathogens on raw fruits and vegetables. Microbes Infect. 4:413423.

3. Chen, L. F., Xu, Y. G., and Fang, Z. D. 1990. Identification of isolates causing root rot of sweet potato and tests on resistance of varieties of sweet potato to root rot. Agric. Sci. 6:27.

4. Clark, C. A. 1992. Postharvest diseases of sweet potatoes and their control. Postharvest News Inf. 3:75-79.

5. Clark, C. A., and Hoy, M. 1994. Identification of resistance in sweet potato to Rhizopus soft rot using two inoculation methods. Plant Dis. 78:1078-1082.

6. Clark, C. A., and Moyer, J. W. 1988. Compendium of Sweet Potato Diseases. American Phytopathological Society Press, St. Paul, MN.

7. d'Enfert, C. 1997. Fungal spore germination: Insights from the molecular genetics of Aspergillus nidulans and Neurospora crassa. Fungal Genet. Biol. 21:163-172.

8. Eckert, J. W., and Ogawa, J. M. 1988. The chemical control of postharvest diseases: Deciduous fruits, berries, vegetables and root/tuber crops. Annu. Rev. Phytopathol. 26:433-469.

9. Ekundayo, J., and Carlile, M. 1964. The germination of sporangiospores of Rhizopus arrhizus; spore swelling and germ-tube emergence. Microbiology 35:261-269.

10. Emri, T., Molnár, Z., and Pócsi, I. 2005. The appearances of autolytic and apoptotic markers are concomitant but differently regulated in carbonstarving Aspergillus nidulans cultures. FEMS Microbiol. Lett. 251:297303.

11. Emri, T., Molnár, Z., Szilágyi, M., and Pócsi, I. 2008. Regulation of autolysis in Aspergillus nidulans. Appl. Biochem. Biotechnol. 151:211220 .

12. Emri, T., Molnár, Z., Veres, T., Pusztahelyi, T., Dudás, G., and Pócsi, I. 2006. Glucose-mediated repression of autolysis and conidiogenesis in Emericella nidulans. Mycol. Res. 110:1172-1178.

13. Feng, Q., Yun, R. S., Li, W., and Guang, C. 1995. Sampling methods in test for resistance of sweet potato to black rot Ceratocystis fimbriata. Acta Agron. Sin. 21:540-543.

14. Gavrieli, Y., Sherman, Y., and Ben-Sasson, S. A. 1992. Identification of programmed cell death in situ via specific labeling of nuclear DNA fragmentation. J. Cell Biol. 119:493-501.

15. Gottlieb, D. 1978. Introduction: Germination. Pages 1-11 in: The Germination of Fungus Spores. D. Gottlieb, ed. Meadow Field Press, Durham, NC.

16. Granot, D., Levine, A., and Dor-Hefetz, E. 2003. Sugar-induced apoptosis in yeast cells. FEMS Yeast Res. 4:7-13.

17. Granot, D., and Snyder, M. 1991. Glucose induces cAMP-independent growth-related changes in stationary phase cells of Saccharomyces cerevisiae. Proc. Natl. Acad. Sci. USA 88:5724-5728.

18. Granot, D., and Snyder, M. P. 1993. Carbon source induces growth of stationary phase yeast cells, independent of carbon source metabolism. Yeast 9:465-479.

19. Holmes, G. J., and Stange, R. R. 2002. Influence of wound type and storage duration on susceptibility of sweet potatoes to Rhizopus soft rot. Plant Dis. 86:345-348.

20. Janisiewicz, W. J., and Korsten, L. 2002. Biological control of postharvest diseases of fruits. Annu. Rev. Phytopathol. 40:411-441.

21. Leiter, E., Szappanos, H. C., Oberparleiter, L., Kaiserer, L., Csernoch, L., Pusztahelyi, T., Emri, T., Pócsi, I., Salvenmoser, W., and Marx, F. 2005. 
Antifungal protein PAF severely affects the integrity of the plasma membrane of Aspergillus nidulans and induces an apoptosis-like phenotype. Antimicrob. Agents 49:2445-2453.

22. Liu, P., Guo, J., Liu, H., Cheng, Y., Wang, B., Long, C. A., and Deng, B. 2009. Diallyl trisulfide (DATS) effectively induced apoptosis of postharvest disease Penicillium expansum of citrus. Ann. Microbiol. 59:675-679.

23. Madeo, F., Herker, E., Wissing, S., Jungwirth, H., Eisenberg, T., and Fröhlich, K. U. 2004. Apoptosis in yeast. Curr. Opin. Microbiol. 7:655-660.

24. Medwid, R. D., and Grant, D. W. 1984. Germination of Rhizopus oligosporus sporangiospores. Appl. Environ. Microbiol. 48:1067-1071.

25. Moline, H. E., and Lipton, W. J. 1987. Market diseases of beets, chicory, endive, escarole, globe artichokes, lettuce, rhubarb, spinach, and sweet potatoes. U. S. Dep. Agric. Agric. Handb. No. 155.

26. Mousavi, S. A., and Robson, G. D. 2003. Entry into the stationary phase is associated with a rapid loss of viability and an apoptotic-like phenotype in the opportunistic pathogen Aspergillus fumigatus. Fungal Genet. Biol. 39:221-229.

27. Nelson, S. C. 2009. Rhizopus Soft Rot of Sweet Potato. University of Hawaii at Manoa, College of Tropical Agriculture and Human Resources, Cooperative Extension Service.

28. O'Brien, J., Wilson, I., Orton, T., and Pognan, F. 2000. Investigation of the Alamar Blue (resazurin) fluorescent dye for the assessment of mammalian cell cytotoxicity. Eur. J. Biochem. 267:5421-5426.
29. Pitt, J. I., and Hocking, A. D. 2009. Zygomycetes. Pages 145-168 in: Fungi and Food Spoilage, 3rd ed. J. I. Pitt and A. D. Hocking, eds. Springer, Dordrecht, Heidelberg, London, New York.

30. Ray, R. C., Chowdhury, R. S., and Balagopalan, C. 1994. Minimizing weight loss and microbial rotting of sweet potato (Ipomoea batatas) in storage under tropical ambient conditions. Adv. Hortic. Sci. 8:159-163.

31. Ray, R. C., Misra, R. S., and Ghose, P. K. 1997. Spoilage of sweet potato tubers in tropics. III. Soft rot by Rhizopus oryzae L. Adv. Hortic. Sci. 11:103-108.

32. Robson, G. D. 2006. Programmed cell death in the aspergilli and other filamentous fungi. Med. Mycol. 44:109-114.

33. Teper-Bamnolker, P., Dudai, N., Fischer, R., Belausov, E., Zemach, H., Shoseyov, O., and Eshel, D. 2010. Mint essential oil can induce or inhibit potato sprouting by differential alteration of apical meristem. Planta 232:179-186.

34. Thanh, N. V., Rombouts, F. M., and Nout, M. J. 2005. Effect of individual amino acids and glucose on activation and germination of Rhizopus oligosporus sporangiospores in tempe starter. J. Appl. Microbiol. 99:1204-1214.

35. Wendland, J. 2001. Comparison of morphogenetic networks of filamentous fungi and yeast. Fungal Genet. Biol. 34:63-82.

36. Yang, H., Ren, Q., and Zhang, Z. J. 2006. Chromosome or chromatin condensation leads to meiosis or apoptosis in stationary yeast (Saccharomyces cerevisiae) cells. FEMS Yeast Res. 6:1254-1263. 